UDC 581.143.01.07

(C) 2017

N. Taran, Doctor of Biological Sciences

M. Musiyenko, Academician of the National Academy of Sciences, Doctor of Biological Sciences

L. Batsmanova, Candidate of Biological Sciences

N. Grudina,

A. Artiushenko,

B. Storojenko, Candidate of Biological Sciences

Taras Shevchenko National University of Kyiv

\title{
MORPHOLOGICAL PHENOTYPING OF CULTIVARS OF WINTER WHEAT FOR SELECTION OF GENOTYPES WITH HIGH ADAPTIVE POTENTIAL
}

The purpose. To carry out phenotyping and screening of cultivars of wheat of steppe ecotype for selection of genotypes with high adaptive potential in conditions of Forest-Steppe. Methods. Field, laboratory, mathematical-statistical.

Results. The methodology of recent trend of phenomenology of plants for selection of genotypes with high adaptive potential in conditions of field screening is offered. Key parameters of phenotyping are analyzed. Conclusions. Phenotyping as integral criterion of physiological state of plants enables to determine boundaries of adaptive variability and extent of durability of genotype. The conducted morpho-physiological phenotyping of cultivars of winter wheat of steppe ecotype in conditions of influence of environmental factors has allowed selecting material of new productive cultivars which biological properties are in the best way fitted for conditions of Forest-Steppe.

Key words: phenotyping, winter wheat, steppe ecotype, xeromorphy.

The problem of intensification of adaptive strategy of agroecosystems under conditions of global climate change and fluctuations of weather conditions is actual now. The practical solution of these problem demands of working out of methods of estimation of adaptive strategies of agrocenosis and forecasting of their ecological equilibrium and resistance to stress factors of environment in consideration of integrated physiological indicators of the functional state of plants $[2,9]$. Objective determination of optimum interrelation between resistance and productivity can be carried out on the basis plant phenotyping $[1,10]$. Phenotyping is methodology of a new direction of plant phenomics. It originally suplemented classical phytophysiology and allows to combine various physiological, morphometric and biochemical processes for understanding of molecular genetic bases of multifunctional process of the general adaptation syndrome of plants. This methodology represents multivariant researches of a complex of the plant 
characteristics, which associated with processes of growth and development of plants, structural reorganization of physiological reactions of tolerance, resistance and ecological plasticity and productivity.

The features of phenotyping is that methods of non-destructive analysis of a phenotype in a combination with genomics allow to study growth and development of plants as reactions to influence of various factors of environment and to give characteristics of concrete varieties of plants in certain conditions. This research expect the analysis of some physiological parameters, that can formed both multiple physiological features and founding the specific reactions to future stress conditions, which formed preadaptation [2]. The last give the chance to plants 'to be prepared' for action of the future difficult environments on plants, and to decrease the rate of plant damage.

The aim of our work was phenotyping and screening of wheat varieties of a steppe ecotype for selection of genotypes with high adaptive potential in conditions of Forest-steppe of Ukraine.

\section{Materials and methods}

The cultivars of winter plants wheat plants of steppe-ecotype Avangard, Shestypalivka, Titona, Odesska 267, Tronka, Skala are selected by "BOR" (Dachne, Odessa region). All varieties were sowed on experimental fields of NNC "Institute of agriculture" UAAN, urban-type community Chabany. These cultivars were characterised by high drought-resistance and had complex resistance to diseases [3]. Leaf area, leaf water retention, xeromorphic features of leaves and morphometric indexes of crop structure were used for estimation of physiological state of plants. For investigation were used flag leaves of plants of main stems of cereals. It's correctly because $80 \%$ of photoassimilates transport from flag leaves to ear in the last stages of organogenesis [7, 9].

For estimation of limits of adaptive variability we tracked the changes of leaf water retention in different phases of plant development [8]. Microscope investigations of xeromorphic features of leaves were spent on 'Bresser LCD micro'. Leaf area of flag leaves was determined by gravimetric method [8]. Analysis of results was carried out by 'Microsoft Excel' and 'STATISTICA 6.0' programs. 


\section{Results}

Specificity of field screening of plants means the most objective estimation of level of a resistance and productivity of wheat cultivars to climatic conditions. This estimation is extraordinarily important in selection practice. In Ukraine from 2007 to 2014 record values of daily average temperature of air in spring-andsummer vegetation have not been registered only in 2008.

The daily average temperatures of air were essentialy higher in comparison with average perennial values in period of reproductive development of winter wheat plants in comparison with average perennial values from 2007 to 2014. In 2013 the elevation of daily average temperature of air over the normal was fixed during 2 weeks, at first small (on $0,8^{\circ}$ ) in phases from earing to flowering, and then more essential (on $1,5^{\circ}$ ) from milky ripeness phase to milky-wax ripeness phase. During flowering-milky-wax ripeness phases period this difference average $1,2{ }^{\circ} \mathrm{C}$. In 2014 the daily average temperatures of air was considerably above norm (on $5,1^{\circ}$ ) during whole period from flowering phase to milky-wax ripeness phase.

In some days the daily average temperature exceeded ordinary values on $8^{\circ} \mathrm{C}$. In particular, in this period excess of daily average temperature has begun for 1,5 weeks prior to the beginning of phase of flowering and has coincided with absence of atmospheric precipitations. The index of humidity of the warm season in May, 2013 was $0,8^{\circ}$ C. In May 2014 it was 0,6. Simultaneously, this average perennial value month was 1,2 for Kiev region during this month. Such weather conditions are essential influenced on plant development, especially on vegetative growth stages.

Leaf area is important morphological phenotyping index for selection of productive cereals [10]. Comparative analysis of winter wheat cultivars has shown, that leaf area of flag leaves was maximal for Avangard cultivar(22,2 $\left.\mathrm{cm}^{2}\right)$. At the same time Titona and Shestypalivka cultivars had large and approximately identical flag leaves $\left(17,84 \mathrm{~cm}^{2}\right.$ and $\left.18,29 \mathrm{~cm}^{2}\right)$ (fig. 1). Flag leaves of plants of Skala cultivar were the least among the plants of all investigated cultivars $(13,42$ $\left.\mathrm{cm}^{2}\right)$.

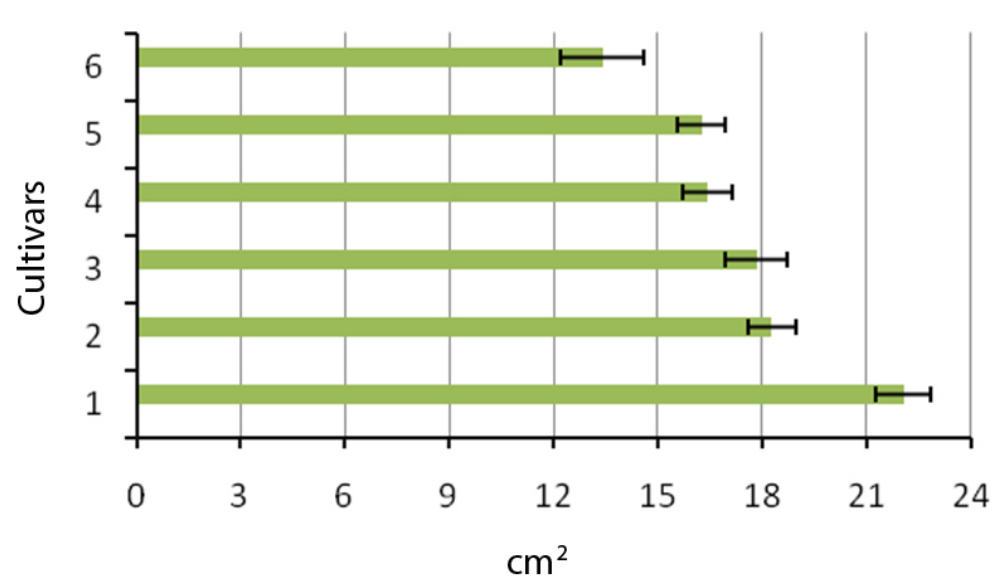


Fig. 1. Leaf area of flag leaves of winter wheat plants in flowering phase: 1Avangard; 2 - Shestypalivka; 3-Titona; 4 - Odesska 267; 5-Tronka; 6 - Skala; hereinafter on fig.

Leaf water retention is integrated feature which reflect adaptive metabolism of plants and their ability to keep water with help of membrane barriers [6, 12]. Based on obtained results the maximal capacity to retain water in critical period of water deficit of plants (milky-wax ripeness phase) had plants of Titona, Tronka and Shestypalivka cultivars (fig. 2).

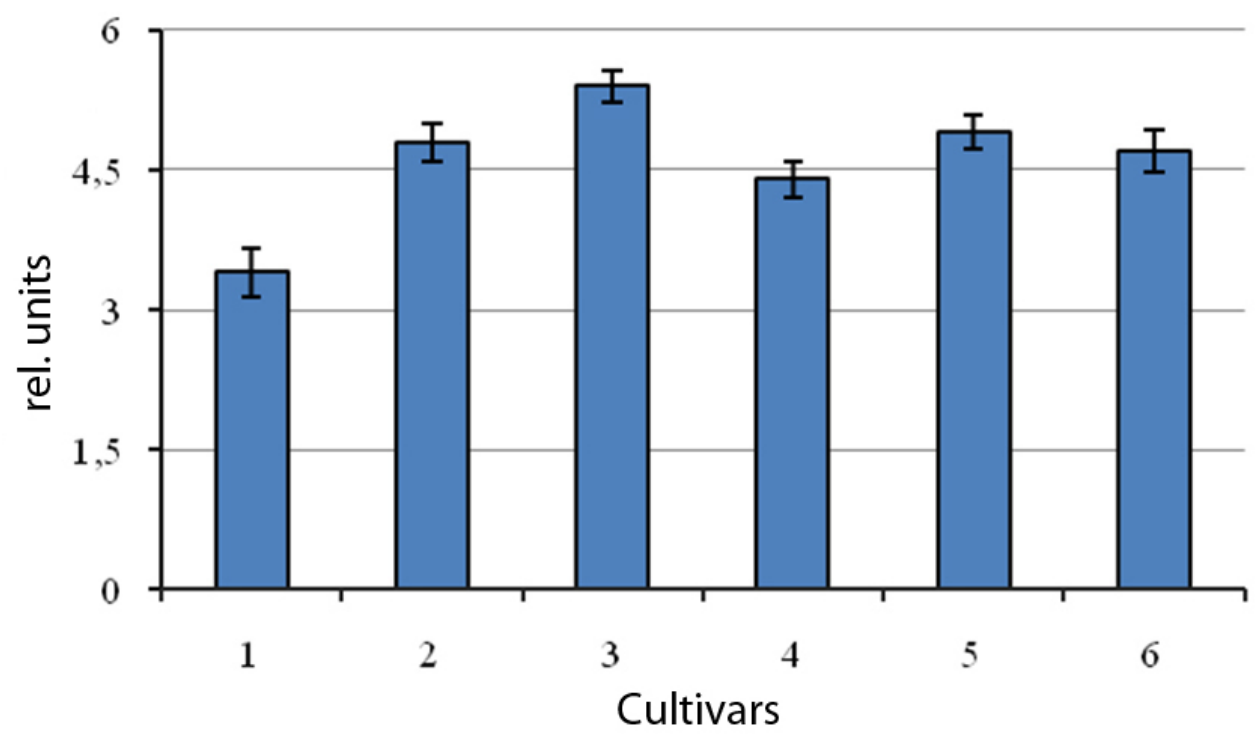

Fig. 2. Leaf water retention of wheat plants in flowering phase.

Phenotyping by xeromorphicity feature of leaf structure has shown, that quantity of stomas varied in investigated plants from 81,8 to 100 pieces $/ \mathrm{mm}^{2}$. This index varied from 110x103 to 211x103 pieces on one leaf. At the same time we assumed, that big quantity of stomas respond to smaller dimensions of cells $[4,5]$. This fact demonstrate the enhanced xeromorphicity of cells. Investigation results demonstrated, that wheat leaves are amphistomatic. Their stomata are located on abaxial and adaxial sides of leaves. The quantity of stomata on the upper side of leaf more than on lower side. In agreement with it the higher xeromorphicity has been observed for Titona, Shestypalivka and Avangard cultivars.

Table 1. Number of stomas on adaxial side of flag leaves of wheat in flowering phase of vegetation 


\begin{tabular}{|l|c|c|c|}
\hline \multirow{2}{*}{ Cultivar } & \multicolumn{3}{|c|}{ Number of stomas, units } \\
\cline { 2 - 4 } & $\begin{array}{l}\text { in } \\
\text { microscopic } \\
\text { field }\end{array}$ & $\mathrm{mm}^{2}$ & flag leaf $\mathrm{x} 10^{3}$ \\
\hline Avangard & 63 & 96 & 211 \\
\hline Shestypalivka & 63 & 96 & 175 \\
\hline Titona & 53 & 80 & 143 \\
\hline Odesska 267 & 60 & 92 & 149 \\
\hline Tronka & 63 & 96 & 127 \\
\hline Skala & 61 & 92 & 124 \\
\hline s-x95\% & 4,1 & 6,5 & 34,7 \\
\hline
\end{tabular}

Physiological screening of formation of adaptable reactions and economic characters of winter wheat cultivars spent by us for agroclimatic conditions of Forest-steppe. It allows us to arrange wheat cultivars in certain sequence in order of decreasing their resistance by as follows Titona, Tronka, Shestypalivka, Skala, Avangard and Odesska 267.

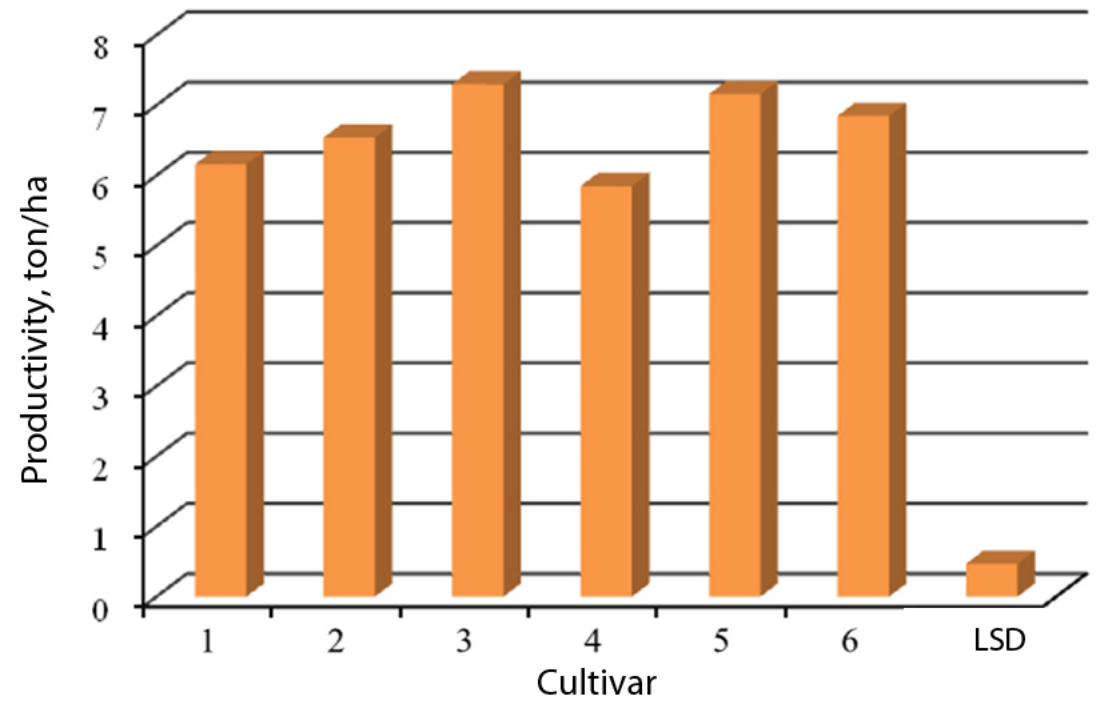

Fig. 3. Average productivity (2013-2014 crop year) of wheat of steepe ecotype The note: least significant difference (LSD) $\leq 0,05$ 
Comparative analysis of genotypes on grain productivity has shown, that the greatest productivity had Titona and Tronka cultivars. The second-best cultivars were Shestypalivka and Skala, that was connected with physiological characteristics of cultivars.

\section{Conclusions}

Phenotyping is used for integral estimation of physiological state of plants. It allows to characterize the limits of adaptive variability and genotype resistance of plants. Due to morphological phenotyping of wheat cultivars we selected the breeding material of new productive cultivars, that are more adaptive to conditions of forest-steppe zone of Ukraine. Phenotyping data agree with estimation of plant productivity, that would allow to select wheat cultivars, which will be adapted to climate conditions of forest-steppe zone. These cultivars are Titona, Tronka and Shestypalivka.

\section{Bibliography}

1. Volkova N.C. Dobir za dopomogoju markeriv ta genomna selekcija v roslynnictvi: teoretychni aspekty / N.C. Volkova //Materialy mizhnar. konf. «Teoretychni osnovi optimizaciï selekcijnogo procesu osnovnih vidiv sil's'kogospodars'kih roslin» - Plejada, 2015. - S. 44-47.

2.Grodzinskij D. M. Adaptivnaja strategija fiziologicheskih processov rastenij / D. M. Grodzinskij - K.: Naukova dumka, 2013. - 301s, - ISBN 978-966-00-1277-6.

3.Dospehov B.A. Metodika polevogo opyta / B. A. Dospehov - M.: Agropromizdat, 1985. - $343 \mathrm{~s}$.

4.Korovec'ka G. Stan prodihovogo apparatu listkiv roslin Carex hirta L. za vplivu naftovogo zabrudnennja gruntu/ G. Korovec'ka, R. Sohan'chak, N. Dzhura. // Visnik L'vivs'kogo universitetu, serija Biologichna.- 2013. -№31.- S. 25-32.

5. Kudojarova G. R. Reakcija ust'ic na izmenenie temperatury i vlazhnosti vozduha u rastenij raznyh sortov pshenicy, rajonirovannyh $\mathrm{v}$ kontrastnyh klimaticheskih uslovijah / G.R. Kudojarova // Fiziologija rastenij.- 2011.- T. 54. № 1. C. 54-58. 
6. Kordjum E.L. Kletochnye mehanizmy adaptacii rastenij k neblagoprijatnym vozdejstvijam jekologicheskih faktorov v estestvennyh uslovijah / E.L. Kordjum. - K.: Naukova dumka, 2003. -271s.

7. Metodyka Derzhavnogo sortovivchennja sil's'kogospodars'kyh kul'tur. Metodiki viznachennja pokaznikiv jakosti roslinnoyi produkciji /pid red.O.M. Gonchara. K.: Al'fa, 2000. - 144 s.

8. Fiziologija Roslyn. Praktikum /[O.V. Vojcehivs'ka,A.V. Kapustjan,O.I. Kosik ta insh.]; pid red. T.V. Parshikova. - L.: Teren, 2010. - 413s. - ISBN № 978-9662276-08-4.

9. Prjadkina G.O. Fiziologichni osnovi pidvyshhennja produktivnosti roslin ozimoyi pshenyci /G.O. Prjadkina. - K.: Interservis, 2014. - 210 s., - ISBN: 978617-696-237-3. 6.

10. Kumar J., A. Pratap A., Kumar S. Phenomics in Crop Plants: Trend, options and limitations - Springer India, 2015. - 8. - 296 p. 